$$
\begin{gathered}
\text { 사육수 비교환방식을 이용한 포장 사육지에서의 } \\
\text { 흰다리새우, Litopenaeus vannamei } \\
\text { (Boone, } 1931 \text { )의 초고밀도 양식 } \\
\text { 조영록·김봉래 }{ }^{1} \text { 장인권* } \\
\text { 국립수산과학원 서해수산연구소 해역산과 } \\
\text { '국립수산과학원 중앙내수면연구소 }
\end{gathered}
$$

\title{
Super-intensive Culture of Whiteleg Shrimp, Litopenaeus vannamei (Boone, 1931), in HDPE-lined Ponds with no Water Exchange
}

\author{
Yeong Rok Cho, Bong Rae Kim ${ }^{1}$ and In Kwon Jang* \\ Aquaculture Industry Division, West Sea Fisheries Research Institute, \\ National Fisheries Research \& Development Institute, Incheon 400-420, Korea \\ ${ }^{1}$ Inland Fisheries Research Institute, National Fisheries Research \& \\ Development Institute, Gapyeong 477-815, Korea
}

Shrimp farming is the most important mariculture industry on the west coast of South Korea. However, it has suffered from mass mortality due to viral disease outbreaks and coastal pollution due to water discharge. This study developed an intensive shrimp culture method for outdoor ponds, without water exchange, which minimizes the chance of viral transmission from the environment, reduces coastal pollution by water discharge and enhances shrimp production. A culture trial was conducted in two high-density polyethylene (HDPE)-lined ponds with a $550 \mathrm{~m}^{2}$ surface area. The ponds were stocked with postlarvae of Litopenaeus vannamei, the major farmed shrimp species in Korea, on July 10, 2007, and cultured for 90 days with no water exchange. The stocking density of the postlarvae (B.W. $0.0015 \mathrm{~g}$ ) was $272 \mathrm{ind} . / \mathrm{m}^{2}$, which is eight times higher than in traditional pond culture in Korea. At harvest, the total production of ponds 1 and 2 was $1,362 \mathrm{~kg}\left(2.48 \mathrm{~kg} / \mathrm{m}^{2}\right)$ and $1,282 \mathrm{~kg}\left(2.33 \mathrm{~kg} / \mathrm{m}^{2}\right)$, respectively. This is $20 \sim 22$ times higher than the mean farmed shrimp production $\left(0.112 \mathrm{~kg} / \mathrm{m}^{2}\right)$ in Korea and about eight times higher than in traditional ponds with a good harvest. Although there was no water exchange throughout the culture period, the mean concentrations of unionized ammonia and nitrite-nitrogen were as low as 0.038 and $6.0 \mathrm{mg} / \mathrm{L}$, respectively. The feed conversion rate (FCR) was 1.38 , which is $20 \sim 45 \%$ lower than that of traditional pond cultures. The high efficiency of the diet in this study is thought to be due to a well-managed feeding strategy and well-developed bioflocs used as diet additions for the shrimp. The final body weight of the shrimp at harvest was low (12.2 12.5 g), compared with that of traditional pond culture. This may have resulted from the combination of a short culture period, high density of shrimp, and low temperature. This study suggests that a super-intensive shrimp pond culture method using biofloc technology with no water exchange can minimize viral transmission via water exchange, reduce coastal pollution, and enhance shrimp production.

Key words: Litopenaeus vannamei, Intensive shrimp culture, Biofloc, No water exchange

서 론

우리나라의 새우양식은 1-3 ha 크기의 축제식 양식장에서 반집약적인 방식으로 이루어지고 있다. 새우 양식생산량은 2001년 3,256 mt을 정점으로 해마다 감소하여 2009년에는 $1,893 \mathrm{mt}$ 에 불과하였으며, 지난 10 년간 단위면적당 생산량도 전국 평균 $1.12 \mathrm{mtha}$ 로서 정상적인 예상 수확량인 $3.0 \mathrm{mtha}$ 에 비해 크게 낮았다 (Jang et al., 2009b; Kim, 2010). 생산성 저하 의 주요 원인 중 하나는 전염성 질병, 특히 WSSV (white spot syndrome virus)에 의한 대량폐사 때문인 것으로 알려져 있다

\footnotetext{
*Corresponding author: jangik@nfrdi.go.kr
}

(Jang et al., 2007a, b, 2009a). WSSV는 1992년 중국에서 최초로 발견된 이래 (Chen, 1995) 아시아, 인도-태평양을 거쳐 1990년 대 말에는 미주를 포함한 전 세계의 새우양식장으로 전파되어 심각한 손실을 가져온 바이러스로서 현재까지도 새우양식산 업에 가장 큰 장애요인이 되고 있다 (Chou et al., 1995; Wang et al., 1995; Lo et al., 1996; Flegel, 1997; Lighter, 1999). 이에 대한 대책의 일환으로 선발육종을 통하여 질병내성과 성장률 이 다른 새우류에 비해 높은 것으로 알려진 흰다리새우, Litopenaeus vannamei (Boone, 1931; Briggs et al., 2004; FAO, 2006)가 2003년 미국 하와이로부터 국내로 이식된 이래 양식 이 확산되어 2007년에는 흰다리새우가 전국 양식새우생산량 
의 $62.5 \%$ 를 점유하게 되었다 (Kim et al., 2004; Jang et al., 2008). 그러나 국내에서 양식되는 대부분의 흰다리새우는 해 마다 외국으로부터 바이러스에 비감염된 SPF (specific pathogen free)의 어미새우 혹은 postlarva를 수입하여 양식장 에 입식되기 때문에 양식장에서의 바이러스 감염은 대부분 양식 중에 환경으로부터의 수평감염 (horizontal transmission) 을 통하여 일어난다 (Jang et al., 2007a, b). 일반적으로 축제식 새우양식장에서는 사육수의 주기적인 환수를 통하여 수질을 유지하는데, 이러한 대규모의 환수는 바이러스 수평감염의 주된 경로가 될 뿐 아니라 부영양염의 배출수에 의한 연안환 경의 악화를 가져온다 (Brock et al., 1997; Flegel, 1997; Lo et al., 2000; Lotz and Lightner, 2000).

사육수의 비교환 (no exchange) 혹은 저교환 (limited exchange) 방식은 병원체의 유입과 환경오염의 문제를 해결하 는 근본적인 방법이지만, 사육수 내의 영양염, 특히 질소노폐 물의 축적이라는 부담이 따른다. 미생물총 (biofloc) 기술을 적용한 축제식 새우양식장에서의 사육수 비교환 방법은 병원 체의 감염을 차단할 뿐 아니라 사육수의 질소노폐물을 효율적 으로 제거함으로써 양식생산성을 크게 향상시킬 수 있어 최근 많은 연구가 이루지고 있다 (McIntosh, 2000; Samocha et al., 2000, 2007; Browdy et al., 2001). 사육수를 교환하지 않을 경우, 양식생물의 생체량과 사료공급량이 증가함에 따라 양식 장의 수용력은 부하가 걸리게 되며, 양식 생산량은 슬러지의 처리 여부에 따라서 크게 달라진다 (Hopkins et al, 1999). 실제 로 대부분의 축제식 새우양식장들은 양식이 진행될수록 사료 찌꺼기, 배설물, 플랑크톤 사체 등으로 인하여 사육지 바닥에 유기물의 슬러지가 축적된다. 슬러지의 축적은 사육수의 부영 양화에도 영향을 미칠 뿐 아니라 혐기상태의 슬러지층을 형성 하는데 이것은 결국 $\mathrm{COD}, \mathrm{BOD}$ 의 증가와 새우에 치명적인 황화수소, 암모니아 등을 발생시킨다. 따라서 이러한 환경은 새우에게 적합한 서식장소를 축소시키며 새우의 성장, 질병, 생존율에 심각한 영향을 미친다 (Boyd and Clay, 2002). 여러 양식장에서는 중앙배수식의 구조 혹은 별도의 침전조 설치 등을 통하여 효율적으로 슬러지를 제거하려는 다양한 시도가 있어 왔다.

그러나 McIntosh (1999)는 사육수를 교환하거나 슬러지를 제거하지 않고, 모든 유기물을 수중에 부상시킴으로써 사육수 의 수질을 유지하면서 고밀도로 새우를 양식하는 방법을 개발 하였다. 이러한 조건은 일반적인 축제식 양식장에서 식물플랑 크톤 우점의 광합성적 자가영양 (photoautotrophic) 혹은 자가 영양 (autotrophic) 상태의 사육수를 타가영양 (heterotrophic) 우점의 상태로 전환시켜 주는데, 충분히 번식한 타가영양세균 은 암모니아성 질소를 세균 단백질로 동화시킴으로써 질소화 합물을 제거한다 (Avnimelech et al., 1994; Avnimelech, 1999; Hopkins et al., 1999). 이때 타가영양세균은 유기탄소 (organic carbon)를 에너지원으로 이용하기 때문에 carbon과 nitrogen의 비율 ( $\mathrm{C} / \mathrm{N}$ ratio)을 조절함으로써 암모니아를 효율적으로 제거 할 수 있다. 타가영양세균들은 유기물에 결합하여 미생물총 (microbial floc 혹은 biofloc)을 형성하는데 새우는 미생물총을
섭식함으로써 사료의 대체 먹이로 이용하는 것으로 알려져 있다. 또한 타가영양세균의 성장은 매우 높고 따라서 암모니 아 제거효율도 자가영양에 비해 높아서 고밀도의 새우양식에 적합하다 (Browdy et al., 2001; Burford and Lorenzen, 2004; Ebeling et al., 2006; Ebling, 2008). McIntosh (2000)는 다양한 크기의 사육지에서의 경험에 근거하여 저밀도보다 고밀도의 양식을 권장하며 준집약적 (semi-intensive) 축제식 양식장의 35 마리 $/ \mathrm{m}^{2}$ 보다 크게 높은 $125-140$ 마리 $/ \mathrm{m}^{2}$ 의 밀도에서 오히 려 안정적으로 수질이 유지된다고 보고했다.

본 연구는 우리나라에서 새우양식의 주종인 흰다리새우를 대상으로 비닐 포장 사육지 (lined pond)에서 사육수를 교환하 지 않고 일반 축제식양식장보다 약 8 배 높은 초고밀도로 양식 함으로써 배출수에 의한 환경오염의 감소와 바이러스 수평감 염의 예방 및 생산성을 크게 향상시킬 수 있는 기술을 개발하 고자 한다.

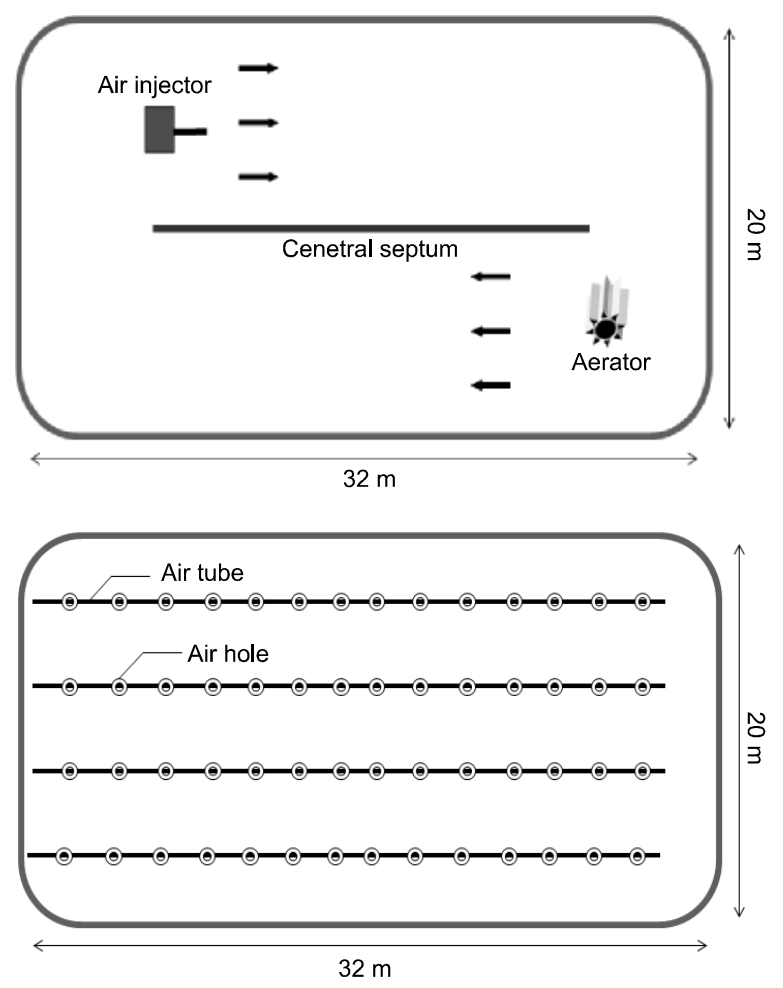

Fig. 1. Layout of ponds 1 (upper) and 2 (lower). Pond lined with HDPE plastic sheet. Pond 2 provided with DPD system for aeration.

\section{재료 및 방법}

\section{사육지와 사육수 준비}

사육실험은 국립수산과학원 서해수산연구소 양식연구센 터(충남 태안군 근흥면) 내에 시설된 2개의 사육지에서 실시 되었다. 사육지의 크기는 $32 \times 20 \mathrm{~m}$ (수면적 $30 \times 18.3 \mathrm{~m}$, $550 \mathrm{~m}^{2}$ )이며 사육지 바닥과 내벽은 모두 검정색의 HDPE (high density polyethylene) 재질로 포장하였다 (Fig. 1). Pond 1은 
중앙을 따라 콘크리트 격벽을 설치하여 사육수가 순환할 수 있도록 하였으며 사육수 순환과 산소공급을 위하여 paddle 형 수차 $(1 \mathrm{HP})$ 와 에어인젝터 $(1 \mathrm{HP})$ 를 각 1 대씩을 설치하였다. Pond 2에는 바닥에 저층분사용 에어공급관 4 개를 설치하고 각 관은 에어블로와 (air blower)에 연결하였다. 에어공급관은 polyethylene 재질로서 $30 \mathrm{~cm}$ 간격으로 구멍 $(\varnothing 2 \mathrm{~mm})$ 을 뚫어 공기가 분사될 수 있도록 하였다. 사육수는 자연해수를 단계 적으로 $100 \mu \mathrm{m}$ 까지 여과하여 sodium hypochlorite (염소농도 $20 \mathrm{mg} / \mathrm{L}$ )로 소독을 실시한 후 1 주일간 폭기하여 염소가 충분 히 제거된 상태에서 시비를 하였다. 시비는 요소, 인산염, 규산 나트륨으로 N:P:Si의 비율이 2.0:0.1:1.5의 농도로 실시하였으 며, 별도 배양된 Chaetoceros spp.를 $10^{2} \mathrm{cell} / \mathrm{mL}$ 농도로 접종하 여 사육수를 안정화시켰다. 초기의 사육수는 사육수 비교환방 식에 따른 증발량을 고려하여 지하수를 혼합하여 약 $25 \mathrm{psu}$ 로 조절하였다. 새우의 사료 섭식량을 조사하기 위하여 사육지의 가장자리에 목재로 가교를 시설하여 사육지별 2개의 먹이망 (feeding tray, $50 \times 50 \mathrm{~cm}$ )을 설치하였다.

\section{종묘입식과 사육관리}

2007년 7월 10일 양식연구센터에서 생산된 바이러스 비감 염 (SPF, specific pathogen free) 흰다리새우 (L. vannamei)의 유생 (PL $\left.\mathrm{PL}_{10-15}, \mathrm{~B} . \mathrm{W} .0 .0015 \mathrm{~g}\right)$ 을 각 사육지별 150,000 마리 $\left(272.7 / \mathrm{m}^{2}\right)$ 씩 입식하여 10 월 8 일까지 90 일간 사육하였다. 먹이 는 새우용 $\mathrm{EP}$ 사료 (crude protein $38 \%$ )를 4회/일 공급하였으며 사료양은 주간성장률 및 먹이망의 조사에 근거하여 매주 결정 하였다. 주간성장률 (weekly growth rate, WGR)은 투망을 이용 하여 pond 별 50-100마리의 새우를 3회 채집한 평균 체중에 근거하여 계산하였다. 사육수는 전 기간 동안 수질향상을 위 해서는 교환하지 않았으나, 증발수의 보충 및 식물플랑크톤의 과잉 번식 시 일부를 교환하여 평균 교환율은 $0.1 \%$ /day 이하였 다.

\section{수질환경 측정}

수온, 용존산소 (DO), 염분은 YSI-85 model (Yellow Springs Instrument Co., Ohio, USA)을 이용하여 매일 2회 측정하였으 며, $\mathrm{pH}$ 는 YSI-6600 pH meter로 매일 1회, TAN (total ammonia nitrogen), $\mathrm{NO}_{2}-\mathrm{N}$, alkalinity는 수질분석용 calorimetric kit (Merck Co., Germany)를 이용하여 매일 1회 측정하였다. 암모 니아 농도의 증가시 탄소원으로 공급된 당밀은 일일 평균으로 환산하였다.

Table 1. Summary of selected water quality parameters in ponds 1 and 2 during a 90-day grow-out trial (mean and range)

\begin{tabular}{|c|c|c|c|c|c|c|c|}
\hline $\begin{array}{l}\text { Water } \\
\text { Temp.(C) }\end{array}$ & $\begin{array}{c}\mathrm{DO} \\
\text { (mg/L) }\end{array}$ & $\begin{array}{l}\text { Salinity } \\
\text { (psu) }\end{array}$ & pH & $\begin{array}{c}\text { TAN } \\
(\mathrm{mg} / \mathrm{L})\end{array}$ & $\begin{array}{l}\mathrm{NO}_{2}-\mathrm{N} \\
(\mathrm{mg} / \mathrm{L})\end{array}$ & $\begin{array}{c}\text { Alkalinity } \\
\text { (mg/L) }\end{array}$ & $\begin{array}{l}\text { Water } \\
\text { exchange } \\
\text { (\%/day) }\end{array}$ \\
\hline Pond $1 \begin{array}{c}25.3 \\
19.0-30.9\end{array}$ & $\begin{array}{c}5.81 \\
3.84-7.49\end{array}$ & $\begin{array}{c}25.3 \\
21.8-28.1\end{array}$ & $\begin{array}{c}7.44 \\
7.15-8.23\end{array}$ & $\begin{array}{c}2.7 \\
0-10.0\end{array}$ & $\begin{array}{c}6.0 \\
0-21.0\end{array}$ & $\begin{array}{c}126 \\
95-170\end{array}$ & $<0.1$ \\
\hline Pond $2 \begin{array}{c}25.3 \\
19.8-30.7\end{array}$ & $\begin{array}{c}5.75 \\
3.36-7.17\end{array}$ & $\begin{array}{c}25.6 \\
22.2-28.5\end{array}$ & $\begin{array}{c}7.43 \\
7.01-8.19\end{array}$ & $\begin{array}{c}2.43 \\
0-10.0\end{array}$ & $\begin{array}{c}5.3 \\
0.24 .0\end{array}$ & $\begin{array}{c}125 \\
95-170\end{array}$ & $<0.1$ \\
\hline
\end{tabular}

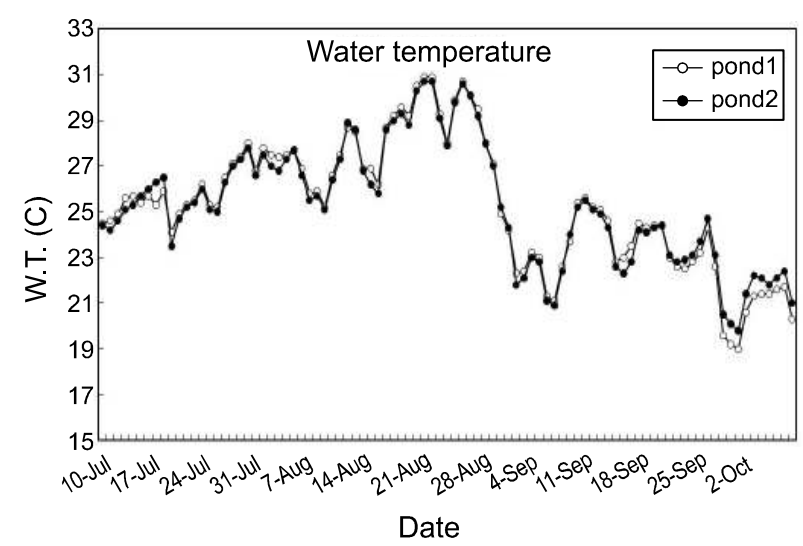

Fig. 2. Change of water temperature in ponds 1 and 2 during a 90-day grow-out trial.

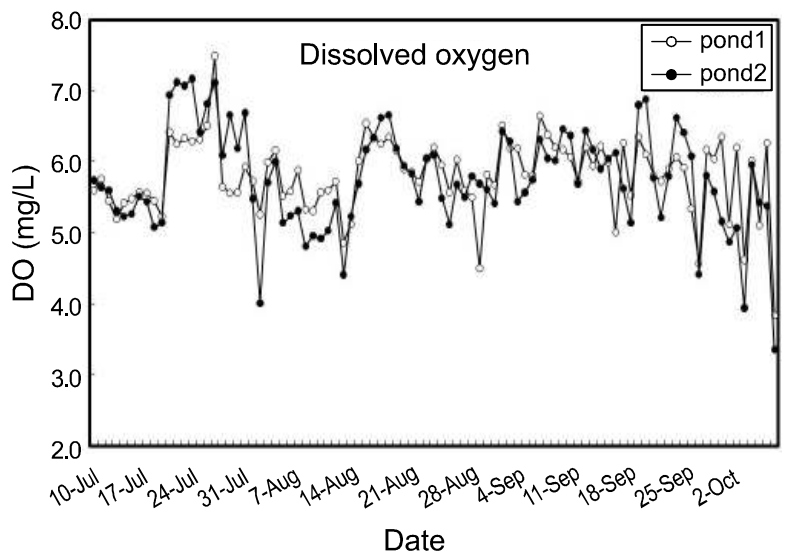

Fig. 3. Change of dissolved oxygen in ponds 1 and 2 during a 90-day grow-out trial.

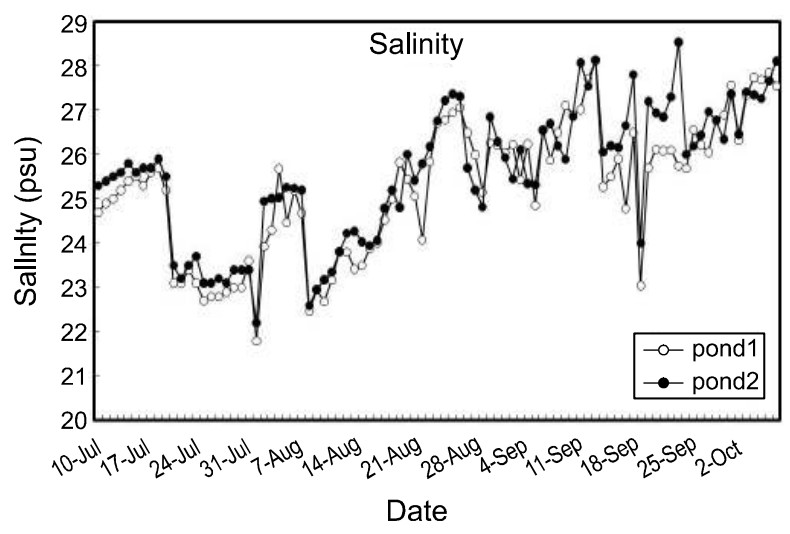

Fig. 4. Change of salinity in ponds 1 and 2 during a 90-day grow-out trial.

$$
\text { 결 과 }
$$

사육수 수질환경의 변화

2007년 7월 10일부터 10월 8일까지 90일간 흰다리새우를 사육한 2 개의 HDPE-lined pond의 수질환경요인의 평균값과 
범위는 Table 1에 나타나 있다. Pond 1과 2의 수온은 사육 시작부터 점차 상승하여 8 월 20 일경 $30^{\circ} \mathrm{C}$ 이상을 보인 후에 급격하게 하강하기 시작하여 9 월 초에 $21^{\circ} \mathrm{C}$ 까지 내려갔다. 이후 $25^{\circ} \mathrm{C}$ 전후까지 상승하였지만 10 월초에 $20^{\circ} \mathrm{C}$ 이하로 떨어 져 10 월 8 일 사육을 종료하였다. Pond 1 과 2 의 평균 수온은 모두 $25.3^{\circ} \mathrm{C}$ (range 19.0-30.9 ${ }^{\circ} \mathrm{C}$ )이었다 (Fig. 2), 용존산소 (DO) 농도는 사육기간 마지막의 1-2일간을 제외하고는 모두 4.0 $\mathrm{mg} / \mathrm{L}$ 이상을 유지하였으며 pond 1이 평균 $5.81 \mathrm{mg} / \mathrm{L}$ (3.84-7.49 $\mathrm{mg} / \mathrm{L}$ ), pond 2가 $5.75 \mathrm{mg} / \mathrm{L}$ (3.36-7.17 mg/L)이었다(Fig. 3). 사육수 비교환방식에 따른 증발량을 고려하여 실험 시작시 사육수는 일반해수에 지하수를 혼합하여 약 $25 \mathrm{psu}$ 이었다 (Fig. 4). 사육 초기 염분은 약간 상승한 후 7 월 20 일 이후의 장마로 인하여 7월말에는 $22 \mathrm{psu}$ 까지 하강한 이후 점차 상승하여 9월 에는 $28 \mathrm{psu}$ 이상까지 높아졌다. Pond 1 과 2 의 염분은 각각 평균 $25.3 \mathrm{psu}$ (21.8-28.1 psu), $25.6 \mathrm{psu}$ (22.2-28.5 psu)를 보였다. $\mathrm{pH}$ 는 초기 1 개월 동안에는 8.2 에서 약 7.2 까지 지속적으로 떨어진 이후 8월부터는 7.1-7.5 범위를 유지하였다. Pond 1과 2의 평균 $\mathrm{pH}$ 는 각각 $7.44,7.43$ 으로 전체적으로 성장적합 범위 를 크게 벗어나지는 않았다 (Fig. 5).

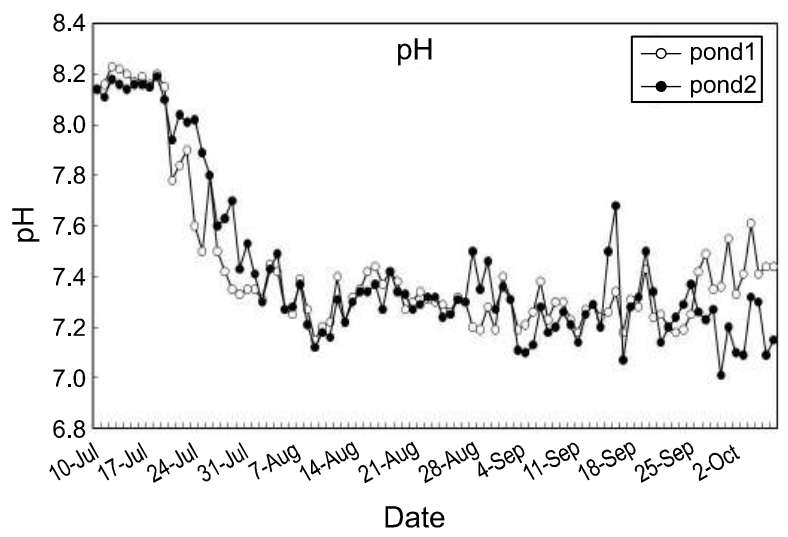

Fig. 5. Change of $\mathrm{pH}$ in ponds 1 and 2 during a 90-day grow-out trial.

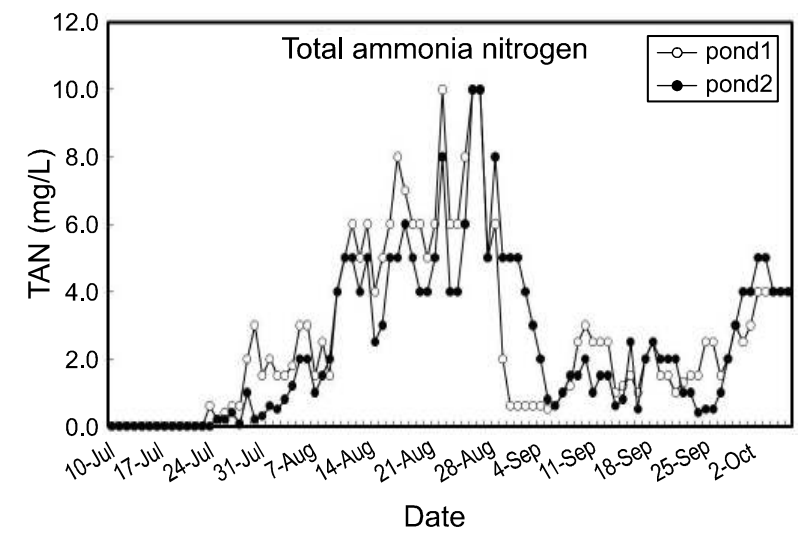

Fig. 6. Change of TAN(total ammonia nitrogen) concentration in ponds 1 and 2 during a 90-day grow-out trial.

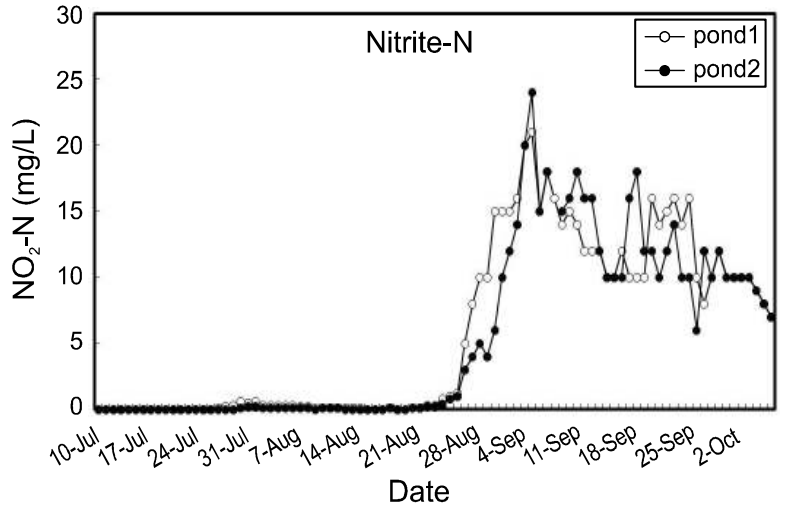

Fig. 7. Change of nitrite-nitrogen concentration in ponds 1 and 2 during a 90-day grow-out trial.

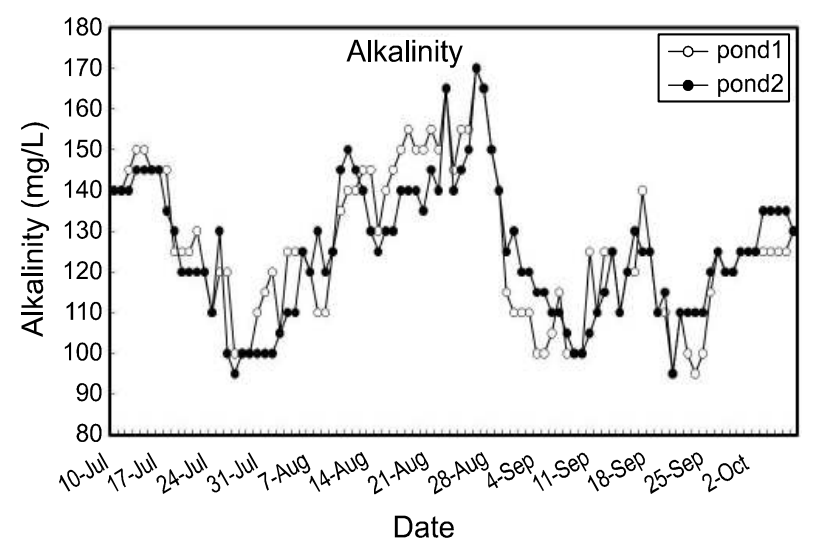

Fig. 8. Change of alkalinity in ponds 1 and 2 during a 90-day grow-out trial.

TAN은 7월 하순부터 상승하기 시작하여 8월 하순에는 10 $\mathrm{mg} / \mathrm{L}$ 까지 증가한 이후 9 월 초순에는 $1.0 \mathrm{mg} / \mathrm{L}$ 까지 감소하였 다. 이후 TAN은 $3.0 \mathrm{mg} / \mathrm{L}$ 전후에서 유지되며 큰 증가를 보이 진 않았다 (Fig. 6). Pond 1과 2에서의 TAN 평균 농도는 각각 $2.70,2.43 \mathrm{mg} / \mathrm{L}$ 이었다. 아질산염 $\left(\mathrm{NO}_{2}-\mathrm{N}\right)$ 농도는 8월 26 일까 지는 $1.0 \mathrm{mg} / \mathrm{L}$ 이하의 낮은 농도를 유지하다가 이후 급격하게 상승하기 시작하여 9월 6일에는 pond 1과 2가 각각 21.0, 24.0 $\mathrm{mg} / \mathrm{L}$ 까지 올라간 이후 점차 낮아지는 경향을 보였다. 평균 아질산염 농도는 pond 1 과 2에서 각각 $6.0,5.3 \mathrm{mg} / \mathrm{L}$ 이었다 (Fig. 7). 아질산염의 증가 패턴은 TAN 농도보다 약 2주일 정도 지연되어 나타나는 경향을 보여주었다. 알칼리도 (alkalinity)는 시작 시 $140 \mathrm{mg} / \mathrm{L}$ 이었으나 7월말에는 $100 \mathrm{mg} / \mathrm{L}$ 까지 점차 감소하였다. 이후 각 사육지에 적당량의 탄산칼슘 $\left(\mathrm{CaCO}_{3}\right)$ 을 살포하여 8월말까지 약 $170 \mathrm{mg} / \mathrm{L}$ 까지 상승하였으 며 이후 점차 감소하는 경향을 보였다 (Fig. 8). Pond 1과 2의 평균 알칼리도 농도는 각각 $126,125 \mathrm{mg} / \mathrm{L}$ 이었다. 사육수는 8월 말, 9월 중순 경 식물플랑크톤의 과잉번식으로 인하여 일부 교환한 것을 제외하고는 수질관리를 위한 교환은 없었으 며 전체 평균 환수율은 $0.1 \% /$ day 이하였다. 
Table 2. Summary of stocking and harvest of L. vannamei in ponds 1 and 2 during a 90-day grow-out trial

\begin{tabular}{|c|c|c|c|c|c|c|c|}
\hline \multicolumn{3}{|c|}{ Stocking } & \multicolumn{3}{|c|}{ Harvest } & \multirow[b]{2}{*}{$\begin{array}{c}\text { survival } \\
(\%)\end{array}$} & \multirow[b]{2}{*}{ FCR } \\
\hline $\begin{array}{l}\text { B.W. } \\
\text { (g) }\end{array}$ & $\begin{array}{c}\text { Total No of } \\
\text { PL }\end{array}$ & $\begin{array}{l}\text { density } \\
\text { (ind. } / \mathrm{m}^{2} \text { ) }\end{array}$ & $\begin{array}{c}\text { B.W. } \\
\text { (g) }\end{array}$ & $\begin{array}{c}\text { total yield } \\
(\mathrm{kg})\end{array}$ & $\begin{array}{c}\text { produc- } \\
\text { tion } \\
\left(\mathrm{kg} / \mathrm{m}^{2}\right)\end{array}$ & & \\
\hline Pond 10.0015 & 150,000 & 272.7 & 12.5 & 1,362 & 2.48 & 72.6 & 1.39 \\
\hline Pond 20.0015 & 150,000 & 272.7 & 12.2 & 1,282 & 2.33 & 70.1 & 1.38 \\
\hline
\end{tabular}

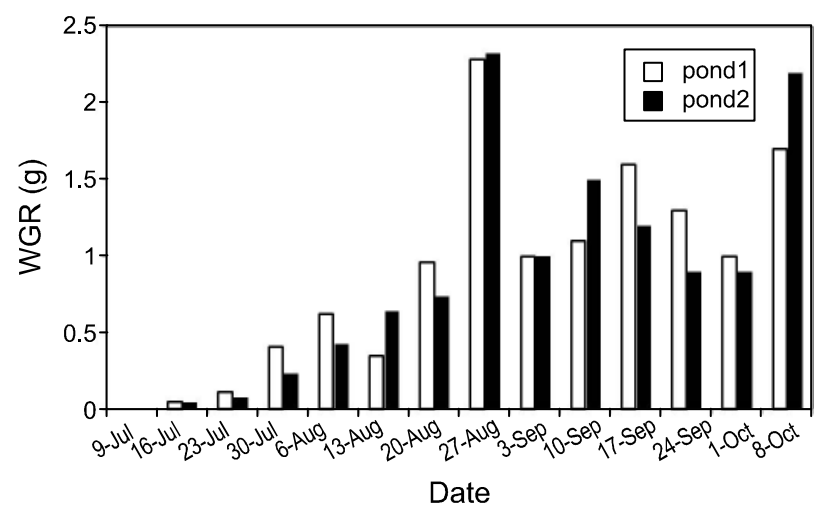

Fig. 9. WGR(weekly growth rate) of $L$. vannamei in ponds 1 and 2 during a 90-day grow-out trial.

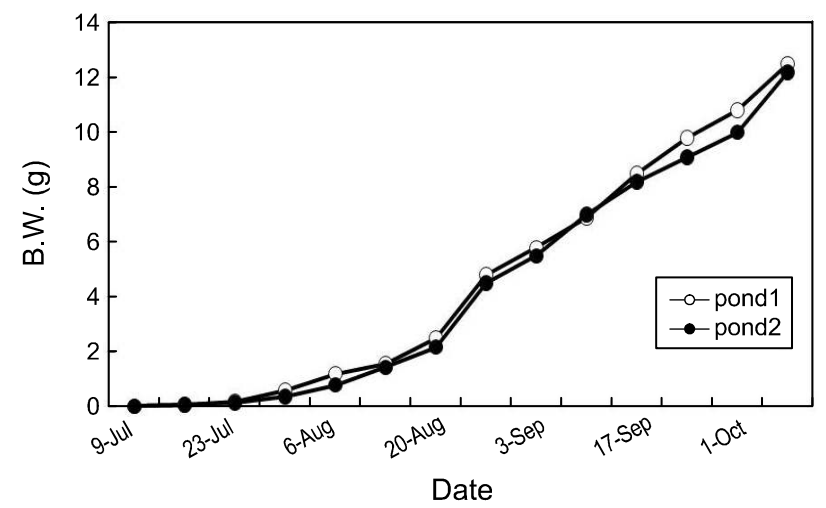

Fig. 10. Changes of mean body weight of L. vannamei in ponds 1 and 2 during a 90-day grow-out trial.

\section{새우의 성장률과 생존율}

9 월 말경부터 사육수의 수온이 $20^{\circ} \mathrm{C}$ 이하로 하강한 관계로 사육 90 일째인 10 월 8 일 새우를 수확하였다. Pond 1과 2의 새우의 생산량과 생존율은 Table 2에 나타나 있다. 총 수확량 은 pond 1 과 2 가 각각 $1,362,1,282 \mathrm{~kg}$ 이며 단위면적당 생산량 은 각각 $2.48,2.33 \mathrm{~kg} / \mathrm{m}^{2}$ 이었다. 수확시 새우의 평균 체중은 각각 $12.5,12.2 \mathrm{~g}$ 이었다. 생존율은 pond 1과 2가 각각 72.6, $70.1 \%$ 이며, FCR (feed conversion rate)은 각각 $1.39,1.38$ 이었 다. Pond 1 과 2의 새우의 체중변화 및 주간성장률은 Fig. 9와 Fig. 10에 나타나 있다. 주간성장률 (weekly growth rate)은 pond 1 과 2가 각각 $0.97,0.95 \mathrm{~g} / \mathrm{week}$ 로서 큰 차이가 나지 않았
다. 주간 성장률은 초기 1 개월 동안은 $0.5 \mathrm{~g} / \mathrm{week}$ 를 넘지 않았 으며 체중이 $2 \mathrm{~g}$ 을 이상이 되는 6주 (8월 20일)까지는 주간성장 률은 $1.0 \mathrm{~g}$ 이하였다. 7 주째인 8 월 말경에는 pond 1 과 2의 주간성장률이 각각 $2.29,2.33 \mathrm{~g}$ 에 달했으며 이후에도 주간성 장률은 $1 \mathrm{~g}$ 이상을 나타냈다.

\section{고 찰}

생산량 및 생존율

$550 \mathrm{~m}^{2}$ 크기의 비닐포장 (HDPE-lined)된 2개의 사육지에서 흰다리새우의 postlarva를 272.2 마리 $/ \mathrm{m}^{2}$ 의 밀도로 입식하고 사육수 교환없이 90 일간 양식한 결과, 총 수확량은 $2,644 \mathrm{~kg}$ 이 었으며 단위면적당 생산량은 23.3-24.8 mt/ha에 달하였다 (Table 2), 일반적으로 우리나라 축제식 새우양식장에서는 30-35 마리 $/ \mathrm{m}^{2}$ 의 postlarva를 입식하여 약 120-150일 후에 수확 하는데, 질병 등의 문제없이 정상적으로 양식할 경우 약 3.0 $\mathrm{mt} / \mathrm{ha}$ 를 생산할 수 있으나 지난 10년간 전국 평균 생산량은 $1.12 \mathrm{mt} / \mathrm{ha}$ 에 머물렀다 (Jang et al., 2007a; Kim, 2010). 본 연구 는 일반 축제식 새우양식장에 비해 8-9배 높게 postlarva를 입식하여 전국 평균 새우양식 생산량의 21-22배, 정상 수확된 양식장에 비해서도 8 배가 높은 생산량을 보여 주었다.

이와 같이 축제식 새우양식장에서의 생산성을 높이기 위한 시도는 외국의 여러 나라에서도 많은 시도가 있었다. Browdy et al. (2001)은 0.25 ha 크기의 HDPE-lined pond에서 104 마리/ $\mathrm{m}^{2}$ 의 밀도로 흰다리새우 종묘를 입식하고 사육수의 교환없이 단백질 함량이 다른 사료를 공급하여 양식한 결과, $\mathrm{CP} 30 \%$ 과 $\mathrm{CP} 40 \%$ 실험구에서 각각 $9.0,10.0 \mathrm{mt} / \mathrm{ha}$ 를 생산하였다. 이들 의 생존율은 $74.5-78.6 \%$ 로서 본 연구의 $70.1-72.6 \%$ 와 비슷하 지만 단위면적당 생산량은 본 연구의 약 $40 \%$ 에 머무르는데 이것은 입식밀도의 차이에 기인하는 것으로 판단된다. McIntosh $(2000,2001)$ 는 중미에 위치한 벨리즈의 새우양식장 에서 다양한 시도를 통하여 사육수 비교환방식을 개발하였는 데, 1998년 이후 매년 생산성이 증가하여 2000년에는 총면적 $13.44 \mathrm{ha}$ 에서 평균 $15 \mathrm{mt} / \mathrm{ha}$ 의 높은 생산량의 흰다리새우를 수확하였다. McIntosh (2001)는 사육수의 교환없이 고밀도로 새우를 사육하는 조건에서는 사료에 어분 대신 탄수화물이 많은 밀이나 옥수수를 사용한 사료를 혼합 공급함으로써 타가 영양세균 (hetertrophic bacteria)의 발달을 촉진시킬 수 있는 것으로 보고하였다. 실제로 그는 grain-based pellet (CP 18.5\%) 를 공급하여 탄소:질소의 비 (C/N ratio)를 20:1까지 상승시킴 으로써 효과적으로 사육수의 암모니아 농도를 크게 낮출 수 있었다. 타가영양세균은 성장을 위하여 탄수화물, 즉 유기탄 소와 암모니아를 필요로 하기 때문에 타가영양상태를 잘 발달 시키기 위해서는 높은 $\mathrm{C} / \mathrm{N}$ ratio를 유지하는 것이 유리한 것으 로 알려져 있다 (Avnimelech, 1999; Ebling, 2008). Samocha et al. (2007)은 $40 \mathrm{~m}^{3}$ 의 raceway형 수조에서 탄소원으로서의 당밀을 다양한 농도로 공급하면서 고밀도로 흰다리새우를 중간육성한 결과, 높은 $\mathrm{C} / \mathrm{N}$ ratio는 암모니아와 아질산염의 농도를 효과적으로 떨어뜨리지만 $7.8 \mathrm{~m}^{3}$ 와 같은 소형수조에 서는 유의적인 차이를 발견하지 못하여 $\mathrm{C} / \mathrm{N}$ ratio는 수조의 
크기 등 사육환경에 따라서 암모니아 제거에 영향을 미친다는 점을 시사하였다. 그러나 소형수조에서의 결과는 사육조건이 라기 보다는 근본적으로 타가영양세균의 종 조성과 군집의 발달 여부에 기인하는 것으로 판단된다. 그러나 현재까지 사 육수 비교환 조건에서의 타가영양세균군의 종 조성과 군집의 변화 등에 대해서는 전혀 연구된 바가 없다. 본 연구에서는 $\mathrm{C} / \mathrm{N}$ ratio나 타가영양세균의 종 조성 등은 분석하지는 않았지 만 CP $38 \%$ 의 배합사료를 사용하면서 암모니아와 아질산염의 농도 변화에 따라서 당밀을 공급함으로써 $\mathrm{C} / \mathrm{N}$ ratio를 높여주 었다.

본 연구에서 얻어진 생산량은 일반 축제식 양식장에 비해 8-22배 높았지만 수확시 새우의 평균 체중은 12.2-12.5 g으로 우리나라의 축제식 양식장에서 생산되는 새우의 평균 체중인 $20 \mathrm{~g}$ 보다 크게 작았다. Browdy et al. (2001)은 본 연구 지역 $\left(36.5^{\circ} \mathrm{N}\right)$ 보다 약간 낮은 위도인 미국의 사우스캐롤라이나 $\left(34^{\circ} \mathrm{N}\right)$ 에서 104 마리 $/ \mathrm{m}^{2}$ 의 밀도로 사육한 결과, 본 연구와 유사한 체중인 11.7-12.6 g의 새우를 수확하였다. McIntosh (2008)는 보다 저위도 국가인 태국 $\left(14^{\circ} \mathrm{N}\right)$ 에서 기후대가 다른 3 개 지역의 양식장을 선정하여 본 연구와 동일한 방식으로 고밀도로 흰다리새우를 양식한 결과, 기온이 높은 남부 양식 장에서는 평균 체중 $18.3 \mathrm{~g}$ 을 얻었으나 동북부와 중부에서는 체중이 각각 $17.5 \mathrm{~g}, 16.2 \mathrm{~g}$ 으로 보고하였다. 이와 같이 고밀도 양식의 경우 새우의 성장률은 저밀도에 비해 낮아질 뿐 아니 라 기후, 즉 수온에도 영향을 받는다. 본 연구 기간동안의 평균 수온은 $25.3^{\circ} \mathrm{C}$ (range $19.0-30.7^{\circ} \mathrm{C}$ )로서 동일 지역의 축제 식양식장에서의 6-9월의 평균 수온 $27.5^{\circ} \mathrm{C}$ (range $21.9-34.2^{\circ} \mathrm{C}$ ) (Jang et al., 2007a)보다 약 $2^{\circ} \mathrm{C}$ 가 낮았으며 사육밀도는 일반 축제식에 비하여 8-9배 높았다. 또한 종묘생산의 지연으로 일반 축제식 양식장의 입식시기인 5-6월보다 크게 늦은 7월 10 일 입식하였기 때문에 양성기간이 1-2개월 짧았다. 본 연구 에서의 낮은 성장률은 이러한 복합적인 이유에 기인하는 것으 로 판단되지만 우리나라에서의 상품 크기인 $20 \mathrm{~g}$ 의 새우를 고밀도로 생산할 수 있는 한계 사육밀도를 확인하기 위해서는 다양한 밀도와 양성기간에 따른 사육실험이 수행될 필요가 있다.

본 연구에서는 CP $38 \%$ 의 사료를 공급하여 1.38-1.39의 FCR (feed conversion rate)을 얻었는데 이것은 일반 축제식 양식장 의 1.7-2.0에 비해 크게 낮으며, Browdy et al. (2001)가 본 연구와 비슷한 조건 하에서 $\mathrm{CP} 30-40 \%$ 를 공급하여 얻은 FCR 1.89-1.92에 비해서도 약 38\%가 낮은 수치이다. McIntosh (2001)는 본 연구와 유사한 고밀도 사육환경 하에서 2.0 의 $\mathrm{FCR}$ 을 얻었으나 사료의 단백질 함량이 $22 \%$ 로 매우 낮았던 점을 고려하면 사료효율이 매우 양호했다고 할 수 있다. 본 연구에서 FCR이 매우 낮았던 이유는 체계적인 사료 관리와 잘 형성된 biofloc 때문으로 판단된다. 효율적인 사료관리 (feed management)는 새우의 생산비를 낮출 뿐 아니라 사육수 수질악화를 감소시키는 중요한 양식관리 요인의 하나이다 (Jory, 1995). 과잉 공급된 사료는 새우의 소화력을 저하시키며 잔량의 사료는 사육지 바닥에 축적되어 수질을 악화시킨다.
뿐만 아니라 사료공급은 새우의 상태, 새우의 분포 상태, 저질 의 상태, 주야간 섭식습성 등에 따라서 적절히 조절하는 것이 바람직하다 (Clifford, 1992). 본 연구에서는 사료의 공급량을 1차적으로 새우의 주간성장률 (weekly growth rate)에 근거하 여 결정하였으며, 부가적으로 사료공급 후 먹이망 (feeding tray)의 조사, 새우의 탈피주기와 날씨의 변화 등을 관찰하여 과잉의 사료가 공급되지 않도록 매일 세심하게 사료 양을 조절하였다. 또 다른 이유로는 잘 형성된 biofloc이 새우의 추가적인 먹이로 이용되었기 때문일 수도 있다. 본 연구에서 biofloc이 어느 정도 형성되었는지를 판단할 수 있는 정확한 지표는 없지만, 앞선 연구결과들에 따르면 본 연구의 사육환 경과 같은 조건에서는 biofloc이 잘 발달되는 것으로 알려져 있다 (Avnimelech, 1999; McIntosh, 2000; Browdy et al., 2001). Avnimelech et al. (1994)는 사육수 비교환방식의 틸라피아 양식장에서 타가영양세균으로 이루어진 미생물총 (microbial floc or biofloc)이 틸라피아에 의해 섭식됨을 관찰하였다. 새우 도 biofloc을 추가적인 먹이원으로 이용한다는 사실이 많이 보고되어 있는데, biofloc은 타가영양세균으로만 구성되기 보 다는 동식물플랑크톤, 유기물 등이 복합적으로 구성되며 다양 한 영양분과 미량원소가 포함되어 새우의 성장, 생존율 및 사료효율에 많은 기여를 하는 것으로 추측된다 (Moss et al., 1999; Browdy et al., 2001; Burford and Lorenzen, 2004; Avnimelech, 2006; Wasielesky et al., 2006).

\section{사육수의 수질환경}

고밀도 양식에서 사육수 내 암모니아성 질소의 축적은 가장 큰 제한요인의 하나이다. 본 실험기간 동안 총암모니아성 질 소 (TAN)는 pond 1 과 2가 각각 $2.7,2.43 \mathrm{mg} / \mathrm{L}$ 로서 이 중 독성이 있는 비이온화 암모니아 (unionized ammonina)는 평균 수온 $25^{\circ} \mathrm{C}, \mathrm{pH} 7.4$ 를 기준으로 환산하면 각각 $0.038,0.034 \mathrm{mg} / \mathrm{L}$ 에 해당한다. 이러한 농도는 새우의 성장 적정 한계인 $0.03 \mathrm{mg} / \mathrm{L}$ 에 근접하지만 만성적으로 영향을 미치는 한계 농도인 0.1 $\mathrm{mg} / \mathrm{L}$ 에는 크게 못 미친다 (van Wky et al., 1999). 새우는 성체 보다 유생시기가 암모니아에 대한 내성이 낮다. 얼룩새우 (Penaeus monodon)의 postlarva의 경우, $96 \mathrm{hr}-\mathrm{LC}_{50}$ 는 $0.2 \mathrm{mg} / \mathrm{L}$ 이지만 (Chen and Chin, 1988), $4.87 \mathrm{~g}$ 의 치하는 $0.95 \mathrm{mg} / \mathrm{L}$ 로 높아진다 (Chen and Lei, 1990). TAN의 농도는 7월말까지 1.0 $\mathrm{mg} / \mathrm{L}$ 를 유지했지만 2개월째인 8월에는 2-10 mg/L로 증가한 후 다시 떨어지는 경향을 보였다. TAN이 높았던 8월의 새우 체중은 1-5 g으로 이 기간 동안의 평균 비이온화 암모니아 농도는 $0.1 \mathrm{mg} / \mathrm{L}$ 보다 낮아 새우의 성장에는 영향을 미치지 않은 것으로 판단된다.

아질산성 질소 (nitrite-N)의 평균 농도는 pond 1 과 2 가 각각 $6.0,5.3 \mathrm{mg} / \mathrm{L}$ 였으며 $\mathrm{TAN}$ 이 감소하는 8 월말부터 급격하게 증가하는 경향을 나타냈다. 아질산염의 형성은 질화과정 (nitrification)의 첫 번째 과정으로 암모니아의 산화에 의하여 만들어지는데 새우의 성장에 적합한 한계농도는 $1.0 \mathrm{mg} / \mathrm{L}$ 이하로 알려져 있다 (van Wky et al., 1999). Chen and Chin (1988)과 Chen and Lei (1990)는 얼룩새우의 암모니아 독성연 
구와 마찬가지로 아질산염에 대한 $96 \mathrm{hr}-\mathrm{LC}_{50}$ 를 조사한 결과, 유생과 치하가 각각 $12.6,171 \mathrm{mg} / \mathrm{L}$ 로 보고하였다. 그러나 흰다리새우는 일반적으로 얼룩새우보다 아질산염에 대한 내 성이 높은 것으로 알려져 있다. Cohen et al. (2005)은 사육수비 교환방식의 흰다리새우의 중간육성에서 아질산염 농도가 26 $\mathrm{mg} / \mathrm{L}$ 로 1 주일간 지속되었으나 새우의 생존과 성장에는 영향 을 미치지 않았으며, Mishra et al. (2008)도 $20 \mathrm{mg} / \mathrm{L}$ 의 아질산 염 농도가 2 주간 계속되었으나 $96.2 \%$ 의 생존율을 얻었다. 본 실험에서 아질산염 농도가 가장 높았던 9월 중 $20 \mathrm{mg} / \mathrm{L}$ 이상은 2 일간 으로 새우의 성장과 생존에 심각한 영향은 미치지 않은 것으로 판단된다. 그러나 9월 동안의 평균 농도는 $13.6 \mathrm{mg} / \mathrm{L}$ 로 서 이 기간의 새우체중 $(5 \mathrm{~g}$ 이상)을 고려하더라도 이러한 농도의 아질산염의 장기간 노출에 의한 영향을 배제할 수는 없다. 본 연구에서 얻어진 새우의 저성장이 수온과 밀도 요인 외에 아질산염의 지속적인 고농도에 기인할 가능성도 있다.

아질산염의 농도가 $\mathrm{TAN}$ 의 감소와 더불어 급격히 증가하는 것은 본 실험에서 자가영양세균 (autotrophic bacteria)에 의한 질산화 과정이 진행되는 증거이다. 타가영양상태가 잘 발달된 축제식 양식장이라도 식물플랑크톤과 Nitrosomonas와 같은 세균에 의한 자가영양에 의한 $\mathrm{TAN}$ 의 질산화과정이 함께 진행 된다 (Boyd and Clay, 2002; Cohen et al., 2005). 본 연구에서는 사육수를 교환하지 않고 추가적인 당밀을 공급함으로써 질소 와 유기탄소의 높은 농도를 지속시키고 충분한 양의 산소와 폭기를 함으로써 타가영양상태의 발달과 biofloc의 형성을 촉 진시켰다. 이와 같은 사육조건 하에서 높은 생산성을 얻었으 나 본 연구에서 타가영양세균이 얼마나 발달하고 우점하였으 며 결과적으로 형성된 biofloc이 본 연구결과에 어느 정도 기여 했는지는 분명하지 않다. Biofloc이 새우의 성장에 미치는 효 과와 같은 일부의 연구 (Wasielesky et al., 2006)을 제외하고는 타가영양세균의 종조성과 기능에 대한 연구는 전무하다. 이러 한 이유 중의 하나는 타가영양세균의 대부분은 배양 불가능한 세균 (unculturable bacteria)으로서 접근방법이 매우 어렵기 때문이다. 향후 GS-FLX 등과 같이 수많은 유전자를 동시에 동정할 수 있는 초고속 pyrosequencing 방법 (Langaee and Ronaghi, 2005; Metzker, 2009) 등을 이용하여 biofloc 사육수의 세균군집에 대한 분석이 필요할 것이다.

본 연구에서는 사육지 내 폭기 방법에 따른 수질과 새우의 성장을 비교하고자 pond 1 과 2에 각각 축제식에 사용되는 전통적인 수차방식과 저층폭기방식을 설치하였다 (Fig. 1). 후자는 일반적으로 PDP (pressure differential piping) system으 로 알려져 있는데, 전통적인 수차에 비해서 여러 가지 장점이 있어 최근 외국의 새우양식장에서는 일부 적용되는 추세이다. 수차의 경우는 $1 \mathrm{HP}$ 로 400-450 kg의 새우를 생산할 수 있지만 $\mathrm{PDP}$ 방식은 $700 \mathrm{~kg}$ 을 생산할 수 있어 에너지 절약효과가 있으며 내구성도 훨씬 길다. 또한 PDP 방법은 수차방식의 사육지에 많이 축적되는 바닥의 슬러지를 효과적으로 분산시 키고 산화시킴으로써 저질의 오염을 방지하며 유속을 감소시 킴으로써 새우의 사료섭식율을 높여줄 수 있는 이점이 있다 (McNeil, 2004). 그러나 본 실험에서는 일반 수차를 설치한 pond 1과 PDP system을 설치한 pond 2 간에 수질환경의 모든 항목에서 유의적인 차이를 보이지 않았으며, 새우의 생산량과 생존율에서도 거의 차이를 보이지 않았다 (Tables 1,2). 이러한 이유는 아마도 본 실험에 사용된 $\mathrm{HDPE}$ 재질로 포장된 소규모 의 사육지에서는 바닥에 슬러지의 축적이 대형의 사육지에 비해 훨씬 적으며 유속에 의한 새우의 섭식에 미치는 영향도 작기 때문으로 판단된다. 그러나 폭기시설 관리 측면에서는 두 pond 간 많은 차이를 보여 주었다. 실험 기간 동안 pond 1 의 수차는 몇 차례 수리를 해야 하는 긴급상황이 발생하였으 나 pond 2 에서는 이러한 문제점이 없었다. 본 연구와 같은 초고밀도 양식장의 경우 수차가 정지될 경우, 용존산소의 급 속한 저하로 인하여 심각한 문제가 발생할 수 있다. 또한 몇 ha 크기의 대규모 축제식 양식장의 경우에서도 많은 수차의 유지관리 비용을 고려한다면 PDP 방식의 적용도 충분히 고려 할 만 한 것으로 사료된다.

$$
\text { 사 사 }
$$

이 논문은 국립수산과학원 연구과제 (갑각류양식 기술개 발, RP-2010-AQ-040)의 지원에 의하여 수행되었음.

\section{참고문헌}

Avnimelech Y, Kochva M and Diab S. 1994. Development of controlled intensive aquaculture systems with a limited water exchange and adjusted carbon to nitrogen ratio. Israeli Journal of AquacultureBamidgeh 46, 119-131.

Avnimelech Y. 1999. Carbon/nitrogen ratio as a control element in aquaculture systems. Aquaculture 176, 227-235.

Avnimelech Y. 2006. Bio-filters: The need for a new comprehensive approach. Aquacult Eng 34, 172-178.

Boyd CE and Clay JW. 2002. Evaluation of Belize Aquaculture, Ltd: A Super-intensive Shrimp Aquaculture System. In: Review report prepared under the World Bank, Network of Aquaculture Centers in Asia-Pacific (NACA), World Wildlife Fund (WWF) and Food and Agriculture Organization of the United Nations (FAO) Consortium Program on Shrimp Farming and the Environment, Bangkok, Thailand, 1-17.

Briggs M, Funge-Smith S, Subasinghe R and Phillips M. 2004. Introductions and movement of Penaeus vannamei and Penaeus stylirostris in Asia and the Pacific. RAP publication 2004/10. FAO Regional Office for Asia and the Pacific, Bangkok, Thailand, $1-92$.

Brock JA, Gose RB, Lightner DV and Hasson K. 1997. Recent developments and an overview of Taura 
Syndrome of farmed shrimp in the Americas. In: Diseases in Asian Aquaculture III. Fish Health Section. Flegel TW and McRae IH, eds. Asian Fisheries Society, Manila, Phillipines, 275-284.

Browdy CL, Bratvold D, Stokes AD and McIntosh RP. 2001. Perspectives on the application of closed shrimp culture systems. In: The new wave, Proceedings of the special session on sustainable shrimp culture. Browdy CL and Jory DE, eds. Aquaculture, The World Aquaculture Society, Baton Rouge, Louisiana, U.S.A., 20-34.

Burford MA and Lorenzen K. 2004. Modeling nitrogen dynamics in intensive shrimp ponds: the role of sediments remineralization. Aquaculture 229, 129-145.

Chen JC and Lei SC. 1990. Toxicity of ammonia and nitrite to Penaeus monodon juveniles. J World Maricult Soc 21, 300-306.

Chen JC and Chin TS. 1988. Joint action of ammonia and nitrite on tiger prawn Penaeus monodon postlarvae. J World Aquacult Soc 19, 143-148.

Chen SN. 1995. Current status of shrimp aquaculture in Taiwan. In: Swimming Through Troubled Water, Proceedings of the Special Session on Shrimp Farming. Browdy CL and Hopkins JS, eds. Aquaculture '95. World Aquaculture Society, Baton Rouge, LA, U.S.A., 29-34.

Chou HY, Huang CY, Wang CH, Chiang $\mathrm{HC}$ and Lo CF. 1995. Pathogenicity of a baculovirus infection causing white spot syndrome in cultured penaeid shrimp in Taiwan. Dis Aquat Org 23, 165-173.

Clifford HC. 1992. Marine shrimp pond management: a review. In: Proceedings of the Special Session on Shrimp Farming. Chamberlain GW, Villalón J and Wyban J, eds. World Aquaculture Society, Baton Rouge, LA, U.S.A., 110-137.

Cohen JM, Samocha TM, Fox JM, Gandy RL and Lawrence AL. 2005. Characterization of water factors during intensive raceway production of juvenile $L$. vannamei using limited discharge and biosecure management tools. Aquacult Eng 32, 425-442.

Ebeling JM, Timmons MB and Bisogni JJ. 2006. Engineering analysis of the stoichiometry of photoautotrophic, autotrophic and heterotrophic removal of ammonia nitrogen in aquaculture systems. Aquaculture 257, 346-358.

Ebeling JM. 2008. Carbon:Nitrogen balance impacts nitrogen removal process in microbial-based aquaculture system. Global Aquaculture Advocate $11,38-40$.

FAO. 2006. State of world aquaculture 2006. FAO technical report, Food and Agriculture Organisation of the United Nations, Fishery Resources Division, Rome, Italy, 1-134.

Flegel TW. 1997. Special topic review: major viral diseases of the black tiger prawn (Penaeus monodon) in Thailand. W J Microbiol Biotech 13, 433-442.

Hopkins JS, Sandifer PA, Browdy CL and Holloway JD. 1999. Comparison of exchange and no-exchange water management for the intensive culture of marine shrimp. J Shellfish Res 13, 441-445.

Jang IK, Cho YR, Lee JY, Seo HC, Kim BL, Kim JS and Kang HW. 2007a. Selective predatory effect of river puffer on WSSV-infected shrimp in culture of shrimp with river puffer under laboratory scale. J Aquacult 20, 270-277.

Jang IK, Jun JC, Jo GJ, Cho YR, Seo HC, Kim BL and Kim JS. 2007b. Polyculture of fleshy shrimp Fenneropenaeus chinensis and white shrimp Litopenaeus vannamei with river puffer Takifugu obscurus in shrimp ponds. J Aquacult 20, 278-288.

Jang IK, Kim JS, Cho KJ, Seo HC, Cho YR, Gopalakannan A and Kim BL. 2008. Intensive culture of the Pacific white shrimp, Litopenaeus vannamei, under limited water exchange. I. Indoor nursery culture of postlarvae. J Aquacult 21, 339-345.

Jang IK, Meng XH, Seo HC, Cho YR, Kim BR, Gopalakannan A, Kim JS. 2009a. A TaqMan real-time PCR assay for quantifying white spot syndrome virus (WSSV) infections in wild broodstocks and hatchery-reared postlarvae of fleshy shrimp, Fenneropenaeus chinensis. Aquaculture 287, 40-45.

Jang IK, Kim JS, Seo HC and Cho KJ. 2009b. Intensive culture of Pacific white shrimp Litopenaeus vannamei under limited water exchang. II. Indoor post-nursery culture of juvenile shrimp. J Aquacult 22, 41-50.

Jory DE. 1995. Feed management practices for a healthy pond environment. In: Swimming Through Troubled Water: Proceedings of the Special Session on Shrimp Farming, Browdy CL and Hopkins JS, eds. Aquaculture '95. World Aquaculture Society, Baton Rouge, LA, U.S.A., 119-143.

Kim BR. 2010. Intensive culture of Pacific white shrimp, Litopenaeus vannamei, with activated suspension pond method (ASM). Ph.D. Thesis, Jeju National University, Korea, 104. 
Kim DH, Kim BR, Kim JS, Seo HC, Kim SK, Kim JH and Jang IK. 2004. Combined effects of temperature and salinity on survival and hemolymph osmoregulation of Litopenaeus vannamei, J Aquacult 17, 246-250.

Langaee T and Ronaghi M. 2005. Genetic variation analyses by pyrosequencing. Mutat Res 573, 96-102.

Lightner DV. 1999. The Penaeid Shrimp Viruses TSV, IHHNV, WSSV and YHV: current status in the Americas, available diagnostic methods and management strategies. J Appl Aquacult 9, 27-52.

Lo CF, Ho $\mathrm{CH}$, Peng SE, Chen $\mathrm{CH}$, Hsu HC, Chiu YL, Chang CF, Liu KF, Su MS, Lotz JM and Lightner DV. 2000. Shrimp Biosecurity: Pathogens and Pathogen Exclusion. In: Controlled and Biosecure Production Systems, Proceedings of a Special Session - Integration of Shrimp and Chicken Models. Bullis RA and Pruder GD, eds. The Oceanic Institute, Waimanalo, Hawaii, U.S.A., 67-74.

Lo CF, Ho CH, Peng SE, Chen CH, Hsu HC, Chiu YL, Chang CF, Liu KF, Su MS, Wang $\mathrm{CH}$ and Kou GH. 1996. White spot syndrome baculovirus (WSBV) detected in cultured and captured shrimp, crabs and other arthropods. Dis Aquat Org 27, 215-225.

Lotz JM and Lightner DV. 2000. Shrimp Biosecurity: Pathogens and Pathogen Exclusion. In: Controlled and Biosecure Production Systems. Bullis RA and Pruder GD, eds. Proceedings of a Special Session - Integration of Shrimp and Chicken Models, The Oceanic Institute, Waimanalo, Hawaii, U.S.A., 67-74.

McIntosh RP. 1999. Changing paradigms in shrimp farming: I. General description. Global Aquaculture Advocate 2, 40-47.

McIntosh, RP. 2000. Changing paradigms in shrimp farming: V. Establishment of heterotrophic bacterial communities. Global Aquaculture Advocate 3, 52-54.

McIntosh RP. 2001. High rate bacterial systems for culturing shrimp. In: Proceedings from the Aquacultural Engineering Society's 2001 Issues Forum. Summerfelt et al., eds. Aquaculture Engineering Society, Shepherdstown, West Virginia, U.S.A., 117-129.

McIntosh RP. 2008. Advancing shrimp farm technologies support greater efficiencies, sustainability. Global Aquaculture Advocate 11, 88-89.

McNeil R. 2004. PDP aeration offers advantages in shrimp production. Global Aquaculture Advocate 7, 24-25.
Metzker ML. 2009. Emerging technologies in DNA sequencing. Genome Res 15, 1767-1776.

Mishra JK, Samocha TM, Patnaik S, Speed M, Gandy RL and Ali A. 2008. Performance of an intensive nursery system for the Pacific white shrimp, Litopenaeus vannamei, under limited discharge condition. Aquacult Eng 38, 2-15.

Moss SA, Pruder GD and Samocha TM. 1999. Environmental management and control: controlled ecosystem and biosecure shrimp growout systems. In: Controlled and biosecure production systems, Preliminary Proceedings of a Special Integration of Shrimp and Chicken Models. Bullis RA and Pruder GD, eds. 27-30 April, Sydney, Australia, World Aquaculture Society, 87-91.

Samocha TM, Patnaik S, Speed M, Ali AM, Burger JM, Almeida RV, Ayub Z, Harisanto M, Horowitz A and Brock DL. 2007. Use of molasses as carbon source in limited discharge nursery and grow-out systems for Litopenaeus vannamei. Aquacult Eng 36, 184-191.

Samocha TM, Blacher T, Cordova J and De Wind A. 2000. Raceway nursery production increases shrimp survival and yields in Ecuador. Global Aquaculture Advocate 3, 66-68.

van Wyk PM. 1999. Harbor Branch Shrimp Production Systems. In: Production of marine shrimp in freshwater recirculating aquaculture systems. Crawford B, ed. Florida Department of Agriculture and Consumer Services, Tallahassee, FL, U.S.A., $1-222$.

Wang CH, Lo CF, Leu JH, Chou CM, Yeh PY, Chou HY, Tung MC, Chang CF, Su MS, Kou GH. 1995. Purification and genomic analysis of baculovirus associated with white spot syndrome (WSBV) of Penaeus monodon. Dis Aquat Org 23, 239-242.

Wasielesky Jr. W, Atwood H, Stokes A and Browdy CL. 2006. Effect of natural production in a zero exchange suspended microbial floc based super-intensive culture system for white shrimp Litopenaeus vannamei. Aquaculture 258, 396-403.

$\begin{array}{llr}\text { 2010년 } & \text { 6월 } & \text { 1일 접수 } \\ \text { 2010년 } & \text { 8월 } & \text { 10일 수정 } \\ \text { 2010년 } & \text { 8월 } & \text { 13일 수리 }\end{array}$

